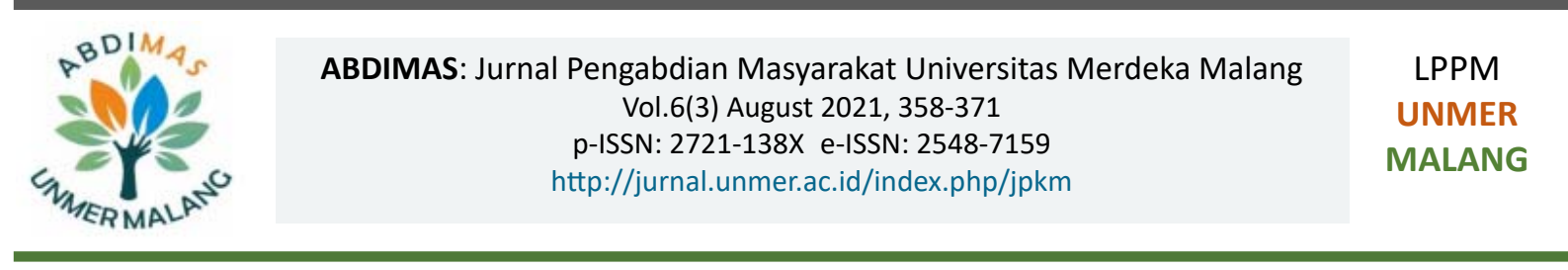

\title{
Optimalisasi Usaha Kecil Menengah melalui Pelatihan Digital Marketing
}

\author{
Saudah Saudah', Dodot Sapto Adi', Maulid Agung Triono², Fajar Supanto² \\ 'Departemen Ilmu Komunikasi, Fakultas Ilmu Sosial dan Ilmu Politik, 2Departemen Manajemen, Fakultas Ekonomi \\ dan Bisnis, Universitas Merdeka Malang, Jl. Terusan Raya Dieng No 62-64 Malang, 65146, Indonesia
}

\section{ARTICLE INFO}

Received: 2021-01-28

Revised: 2021-04-08

Accepted: 2021-06-22

Keywords:

Appropriate

Caption strategy,

Digital marketing,

Photography, Small

and medium industry

\section{ABSTRACT}

The conditions faced by small industries during this pandemic are almost the same as the conditions of the industrial society as a whole. But what distinguishes it is the struggle in producing to marketing products independently. Currently, digital marketing training for small industries provides a measurable support system, due to tactical steps to market products or services to consumers with new breakthroughs. The purpose of this training is to provide easier steps to implement digital marketing applications based on information and communication technology, in order to create consumer attraction for products. The method of implementing this activity is discussion and practice of making captions on social media, online marketing, practicing product photos, forming working groups and presentations. The result of this training is that the participants have awareness in the application of digital marketing to improve the quality of product marketing for small industries more easily.
\end{abstract}

(C)2021 Published by University of Merdeka Malang. This is an open access article distributed under the CC BY-SA 4.0 license (https://creativecommons.org/licenses/by-sa/4.0/)

How to cite: Saudah, S., Adi, D. S., Triono, M. A., \& Supanto, F. (2021). Optimalisasi Usaha Kecil Menengah melalui Pelatihan Digital Marketing. Abdimas: Jurnal Pengabdian Masyarakat Universitas Merdeka Malang, 6(3), 358-371.

https://doi.org/10.26905/abdimas.v6i3.5366

\section{PENDAHULUAN}

Digitalisasi memberikan ruang gerak bagi optimalisasi aktivitas masyarakat, yang didukung oleh penggunaan perangkat teknologi untuk memudahkan pelaku industri kecil dan menengah mengenalkan produknya kepada masyarakat. Pesatnya perkembangan teknologi informasi dan komunikasi membawa dampak pada semakin kuatnya tren pemasaran di lingkungan bisnis, yang pada awalnya menekankan pada strategi konvensional (offline) menjadi digital (online). Digitalisasi memungkinkan pelaku industri serta calon konsumen berinteraksi secara virtual dan pemanfaatan medium untuk menginformasikan produk sesuai dengan keinginan produsen dan juga mengena di benak konsumen. Ketersediaan informasi tidak hanya terbatas pada detail produk, tetapi juga menariknya sebuah desain gambar atau foto yang akan membuat konsumen terkesan. Totalitas dengan dukungan teknologi mampu ditangkap 
oleh pelaku industri sehingga langkah kerja tidak hanya terbatas pada pengenalan produk, namun juga ada peneguhan hingga promosi secara berkelanjutan.

Digital marketing adalah kegiatan promosi serta pemetaan pasar secara digital dengan memanfaatkan jejaring sosial. Konsep pemasaran secara digital mampu menghubungkan orang-orang yang terpisah secara geografis dengan sebuah perangkat teknologi. Digital marketing merupakan konsep pemasaran interaktif terpadu yang memudahkan interaksi antara produsen, konsumen, dan pasar. Ketika pasar secara luas tidak mampu dijangkau dengan mudah oleh produsen, maka strategi dengan memanfaatkan teknologi akan memudahkan meraih pasar yang dimaksudkan. Dengan adanya digitalisasi yang dapat dimanfaatkan secara baik oleh masyarakat, maka pergerakan bisnis akan dapat berjalan dengan maksimal. Masing-masing pegiat IKM tentunya harus memiliki identitas yang akan membedakan dengan yang lain. Identitas dapat digambarkan sebagai konsep yang akan memberikan deskripsi tentang individu atau kelompok yang ada (Saudah \& Adi, 2018).

Digital marketing memberikan kemudahan bagi pelaku industri untuk menyediakan serta memantau segala kebutuhan yang diinginkan oleh konsumen. Di sisi lain, dengan perangkat teknologi, calon kosumen juga dapat mencari informasi terkait produk sesuai dengan yang diinginkan. Calon pembeli akan diberikan sebuah pilihan yang memudahkan mulai dari pemilihan produk, cara pembayaran hingga forum untuk berkomunikasi secara langsung dengan penjual. Berbagai kemudahan yang ditawarkan adalah wujud dari manfaat perkembangan teknologi saat ini.

Pemanfaatan teknologi oleh Industri Kecil dan Menengah (IKM) semakin menunjukkan perkembangan yang signifikan. IKM bergerak dibidang usaha secara mandiri, tidak mengandalkan karyawan dalam jumlah besar dan biasanya bergerak hanya dibantu oleh lingkungan terdekat terutama ada hubungan keluarga. Selain memproduksi secara mandiri, pemasaran juga dilakukan hanya dengan memanfaatkan medium yang dekat dengan keseharian serta menjangkau konsumen secara terbatas. IKM memiliki peran penting dalam pertumbuhan ekonomi Indonesia yang mampu membuka lapangan kerja serta memberdayakan industri rumah tangga untuk mendukung pendapatan keluarga. Keberadaan industri kecil dan menengah pastinya harus terdukung oleh perkembangan teknologi yang menyajikan kemudahan dalam transaksi secara virtual. Optimalisasi penggunaan perangkat teknologi bagi industri kecil dan menengah akan memberikan energi dalam rangka mempertahankan keberlanjutan usaha. Secara nyata iklim kondusif IKM terletak pada peluang besar untuk menjalin relasi dengan komunitas lain, baik dalam bidang yang sama maupun berbeda. Pemanfaatan konsep pemasaran secara digital memberikan harapan besar sebagai sumber kekuatan ekonomi di berbagai wilayah. Teknologi internet yang digunakan sebagai medium pemasaran yang efektif dengan jangkauan yang sangat luas tidak terbatas oleh ruang dan waktu, sehingga pelaku usaha dapat memanfaatkan sebagai sarana untuk meningkatkan jangkauan pasar (Djamaludin et al., 2016).

Perkembangan Teknologi Informasi dan Komunikasi (TIK) saat ini dapat dilihat telah mampu mendorong pertumbuhan ketersediaan informasi yang beragam. Perkembangan ini merupakan peradaban manusia yang diakibatkan oleh adanya kemudahan dalam pemerolehan informasi. Banyak perubahan yang terjadi di masyarakat. Sejauh ini terlihat perkembangan di masyarakat melalui proses 
ABDIMAS: Jurnal Pengabdian Masyarakat Universitas Merdeka Malang

Volume 6, No. 3, August 2021: 358-371

dengan munculnya ide-ide baru atau pesan baru yang ditujukan untuk perubahan. Secara signifikan, perubahan yang ada membawa angin segar di bidang bisnis, khususnya bagi industri kecil dan menengah yang memerlukan dukungan dari semua pihak.

Teknologi sudah mengubah cara manusia berkomunikasi serta beraktivitas. Begitu juga dalam pemasaran yang telah bergerak ke arah digital. Evolusi kegiatan digital marketing semakin kompleks, dimulai dari proses untuk meraih konsumen, membangun preferensi konsumen, mengenalkan produk, hingga meningkatkan penjualan. Dengan digitalisasi, maka peluang IKM untuk masuk dalam kancah industri global semakin terbuka. Selain itu untuk mendukung pengembangan pemasaran berbasis kewirausahaan dengan memanfaatkan e-commerce juga diperlukan bagi industri kecil untuk dapat bersaing di era global (Harini et al., 2017). Platform yang tersedia dapat dimanfaatkan oleh pegiat IKM, dan salah satu yang dapat digunakan untuk meningkatkan pemasaran adalah Google Bisnisku (Ridwan et al., 2019). Platform yang ada semakin memudahkan bergulirnya kegiatan bisnis di berbagai situasi dan kondisi yang terjadi di masyarakat.

Pegiat IKM di Kecamatan Gedangan, Kabupaten Malang sangat potensial, mengingat Kecamatan Gedangan berkembang secara signifikan dalam aspek industri rumah tangga yang tidak hanya berbasis hasil alam. Gedangan adalah sebuah kecamatan di Kabupaten Malang, Provinsi Jawa Timur. Kecamatan ini berjarak sekitar 29 Kilometer dari ibu kota Kabupaten Malang ke arah selatan. Pusat pemerintahan berada di Desa Gedangan, dan kecamatan ini terkenal memiliki banyak pantai indah berpasir putih. Adapun batas wilayahnya sebelah Utara adalah Kecamatan Pagelaran, sebelah Timur adalah Kecamatan Sumbermanjing Wetan, sebelah Selatan adalah Samudera Hindia dan Sebelah Barat adalah Kecamatan Bantur. Berdasarkan kondisi geografisnya, keadaan permukaan tanah datar sampai berombak mencapai $40 \%$ dari seluruh luas wilayah Kecamatan Gedangan, sedangkan sisanya sekitar $60 \%$ merupakan dataran yang berombak berbukit. Masalah ketenagakerjaan di Kecamatan Gedangan adalah tingkat pendidikan yang rendah dan tidak memiliki keahlian, rendahnya tingkat produktivitas masyarakat desa salah satunya disebabkan oleh kurangnya fasilitasi pelatihan khusus untuk warga desa (Malangkab, 2021).

Geografis Kecamatan Gedangan pada umumnya adalah tanah perkebunan dan pertanian. Ada beberapa jenis tanaman yang bisa tumbuh dengan baik di Kecamatan Gedangan, antara lain tebu, padi, jagung, singkong, pisang, dan sayur mayur. Kecamatan Gedangan memiliki lahan yang luas untuk perkebunan tebu, sehingga penghasilan terbesar adalah tebu dan mayoritas penduduknya adalah petani. Hasil panen tebu akan dikirim ke pabrik luar daerah Gedangan yaitu ke pabrik Gula Kerebet dan Kebon Agung Malang. Desa-desa yang berada di Kecamatan Gedangan antara lain Gajahrejo, Gedangan, Girimulyo, Segaran, Sidodadi, Sindurejo, Sumberejo, dan Tumpakrejo.

Wilayah Kecamatan Gedangan juga salah satu penyangga produksi pangan padi di Kabupaten Malang, mengingat kecamatan Gedangan merupakan area persawahan teknis dan non-teknis yang menyebar hampir di semua desa dengan tanaman padi, jagung, ketela, dan kacang tanah. Pisang dan kelapa adalah andalan Kecamatan Gedangan yang termasuk pemasok besar untuk wilayah Malang dan Surabaya. Dengan kondisi wilayah yang jauh dari pusat Kota Malang, Kecamatan Gedangan telah 
membuktikan diri mampu mengembangan berbagai produk hasil dari IKM. Produk industri rumah tangga yang dihasilkan oleh IKM Kecamatan Gedangan adalah batik, kerajinan daur ulang, makanan, minuman, sablon, produk olahan, dan beberapa produk lainnya yang pada dasarnya dapat dengan mudah dijumpai di pasaran. Dengan menghasilkan produk rumahan dengan menjaga kualitas yang ada, maka para pegiat IKM ini memiliki tekad kuat untuk tetap mempertahankan diri berkegiatan sebagai industri rumahan.

Kendala yang dihadapi pegiat IKM adalah minimnya pengetahuan tentang pemasaran online, khususnya terkait dengan penggunaan platform atau fitur yang tersedia pada perangkat teknologi komunikasi yang menyediakan berbagai kemudahan bagi pengguna. Sumber daya manusia memiliki semangat tinggi untuk terus berkembang pada bidang industri rumah tangga, namun belum optimal dalam menfaatkan teknologi yang ada.

Perkembangan teknologi digital memungkinkan para pelaku IKM memasarkan produknya secara online dan melakukan transaksi melalui sistem perbankan secara online juga. Potensi pemanfaatan digital marketing mensyaratkan masyarakat melek teknologi, untuk itu diperlukan pelatihan pengenalan serta pemanfaatan teknologi komunikasi. Kegiatan pelatihan digital marketing diharapkan dapat memberikan pengetahuan dan pemahaman serta dapat menginspirasi pelaku IKM memanfaatkan teknologi untuk memperluas jejaring sosial sebagai medium menjalankan usaha (Purnamasari et al., 2019). Program pengabdian ini bertujuan untuk meningkatkan kapasitas SDM pelaku IKM untuk mengatasi masalah dalam rangka pengembangan dan perluasan pemasaran melalui pemanfaatan teknologi digital secara optimal.

\section{METODE}

Metode yang digunakan pada aktivitas pelatihan digital marketing bagi IKM Kecamatan Gedangan, adalah dengan menggunakan lima metode yang diselenggarakan selama 3 (tiga) hari yaitu pada tanggal 22-24 September 2020. Kegiatan ini bertempat di Gedung KPRI Agung Kecamatan Gedangan Kabupaten Malang Jawa Timur. Pelatihan ini diikuti oleh pelaku IKM se-Kecamatan Gedangan dan sekitarnya. Acara dimulai dengan pembukaan secara resmi yang dihadiri oleh Kepala Dinas Perindustrian dan Perdagangan Kabupaten Malang, Pejabat Camat Gedangan, perwakilan paguyuban IKM dan Narasumber. Kegiatan pelatihan selama tiga hari terjabarkan sebagaimana berikut ini.

\section{Diskusi}

Aktivitas diskusi diawali dengan penyajian materi oleh narasumber dengan tema yang sudah dipilih sesuai dengan kebutuhan dari peserta pelatihan, yaitu tentang pembuatan caption pada media sosial yang lekat dengan konsep copy writing. Dilanjutkan dengan materi pemasaran online yang menekankan pada strategi penggunaan platform untuk memasarkan produk. Penyajian materi dimaksudkan untuk memberikan gambaran tentang pentingnya aktivitas yang pegiat IKM terkait dengan digital marketing. 
ABDIMAS: Jurnal Pengabdian Masyarakat Universitas Merdeka Malang Volume 6, No. 3, August 2021: 358-371

Diskusi secara terbuka dilakukan pada sesi presentasi yang dimaksudkan untuk mengetahui lebih jauh kendala yang dihadapi masing-masing pelaku IKM di Kecamatan Gedangan serta mencoba berbagi pengalaman terkait dengan aktivitas pemasaran. Pemberian materi kepada peserta pelatihan disampaikan pada hari pertama kegiatan pelatihan. Hal ini dimaksudkan untuk membangkitkan kembali motivasi peserta akan tujuan membangun usaha yang ditekuni hingga saat ini.

Dengan komunikasi dua arah antara narasumber dan peserta pelatihan, maka aktivitas membuka wawasan untuk mengali lebih jauh pengalaman dari masing-masing peserta pelatihan dapat berjalan dengan lancar. Pada sesi diskusi terdapat hal menarik, yaitu masing-masing peserta pelatihan akhirnya memiliki kepercayaan diri untuk mengungkap persoalan yang selama ini dihadapi, dan juga mampu menerima solusi yang ditawarkan untuk menjadi solusi terhadap kendala yang ada.

\section{Praktik pembuatan caption pada media sosial}

Selepas sesi presentasi dan diskusi, selanjutnya adalah praktik pembuatan caption pada media sosial, baik itu Facebook maupun Instagram. Selain itu juga strategi memberikan caption pada status Whatsapp yang selama ini dimanfaatkan untuk promosi produk. Narasumber membagikan kertas kepada peserta pelatihan yang telah dirancang sebelumnya untuk memudahkan peserta pelatihan mengenali keunggulan produk, agar imajinasi tumbuh untuk membuat kata-kata (caption) yang sifatnya menjual. Praktik secara mandiri dimulai dari menuliskan industri masing-masing peserta, pembuatan kalimat pembuka (opening statement), body content, serta kalimat penutup (closing statement). Opening statement memerlukan ide yang tepat, penggunaan kalimat efektif dengan bahasa yang mudah dipahami oleh konsumen dan membawa kesan menarik ketika awal kalimat terbaca oleh konsumen. Untuk body content, peserta bisa memunculkan keunggulan produk serta berbagai penawaran yang menarik. Panjang kalimat tentu saja menjadi pertimbangan pada area ini. Closing statement, peserta diminta memberikan kalimat dengan bahasa yang berbeda dari sebelumnya.

\section{Praktik foto produk}

Praktik foto produk dimaksudkan agar peserta pelatihan dapat memahami sisi menarik dari sebuah foto yang akan diunggah pada media sosial masing-masing peserta. Sejauh ini peserta pelatihan sudah seringkali memanfaatkan smartphone untuk pengambilan foto produk. Namun ada kalanya peserta pelatihan merasa bingung ketika tidak ada ide untuk memperkaya materi foto atau produk, sehingga hasilnya kurang menarik. Untuk memunculkan ide untuk foto produk, peserta masih belum ada bayangan tentang medium yang dapat mendukung untuk menjadikan sebuah foto dalam kategori menarik. Pada pelatihan ini, disediakan perangkat foto dan masing-masing peserta, akan mendapatkan perangkat tersebut untuk dapat dipakai praktik secara langsung. Dengan peralatan yang ada maka peserta pelatihan dapat secara langsung praktik foto, dan aktivitas ini dilakukan masing-masing peserta. Sebelum praktik, narasumber memberikan penjelasan tentang teknik foto, dan membantu setting smartphone milik masing-masing peserta untuk dapat digunakan membuat foto produk. 


\section{Pembentukan kelompok kerja}

Pembentukan kelompok kerja pada pelatihan ini dimaksudkan, agar peserta pelatihan dapat berinteraksi secara intens, dapat berbagi pengalaman, atau saling mengevaluasi terkait strategi pemasaran yang selama ini dijalankan peserta, dan dimaksudkan juga untuk melatih kekompakan tim. Selain itu, pembentukan kelompok ini juga dapat dijadikan medium untuk menemukan sebuah strategi baru dalam menyiasati kendala yang selama ini dialami oleh IKM. Peserta pelatihan berjumlah 30 orang dari IKM di Kecamatan Gedangan. Masing-masing kelompok akan menentukan produk yang dipilih untuk difoto dan kemudian dilakukan sesi diskusi untuk mengkaji sisi positif, serta beberapa aspek yang masih harus mendapatkan perhatian. Masing-masing peserta pelatihan dalam sebuah kelompok pada saat berkontribusi terhadap foto produk tidak hanya sebatas pada ide saja, namun kerjasama tim akan terlihat nyata mulai dari persiapan bahan dan dilanjutkan dengan aktivitas lain sampai evaluasi.

\section{Presentasi}

Presentasi dilakukan pada hari ke-3 pelatihan dan masing-masing kelompok dapat menjelaskan kepada forum terkait dengan aktivitas yang sudah dijalankan oleh kelompok mulai dari memilih material foto, melakukan editing terhadap foto produk, mempersiapkan caption, sampai pemilihan platform untuk mengenalkan produk kepada masyarakat. Pada saat presentasi, dipilih satu orang untuk mempresentasikan hasil kerja kelompok. Kerja keras yang dilakukan selama tiga hari dapat membuktikan, bahwa pelatihan ini cukup efektif untuk bisa memberikan gambaran kepada peserta pelatihan tentang pentingnya digital marketing bagi IKM. Pada sesi presentasi, narasumber akan memberikan evaluasi secara keseluruhan terhadap hasil kerja kelompok, sehingga respon secara langsung tepat sasaran, karena dapat menemukan solusi secara bersama-sama.

\section{HASIL DAN PEMBAHASAN}

\section{Hasil}

Pelatihan digital marketing dilaksanakan selama 3 (tiga) hari secara efektif, dimulai pukul 09.0015.00 WIB. Dalam jangka waktu tiga hari, peserta pelatihan mendapatkan pemahaman secara pragmatis dan teknis, sehingga memiliki bekal yang cukup dan dapat dimanfaatkan secara berkelanjutan untuk mengelola medium yang digunakan untuk mengenalkan dan memasarkan produk. Sesi materi tentang digital marketing membuka wawasan peserta pelatihan, dan mengingatkan kembali strategi konvensional yang selama ini digunakan oleh peserta pelatihan, akan semakin efektifjika ditunjang dengan penggunaan internet secara berkelanjutan. Pemanfaatan internet memungkinkan pelaku IKM meraih pasar global dan mensyaratkan kesiapan sumberdaya manusia untuk dapat menggunakan internet secara bijak. Keseimbangan antara pendekatan pragmatis dan teknis pada pelatihan ini, membawa manfaat bagi semua pihak yang terlibat dalam pelatihan. Materi yang didapatkan oleh peserta pelatihan terjabarkan dalam Tabel 1. 
ABDIMAS: Jurnal Pengabdian Masyarakat Universitas Merdeka Malang

Volume 6, No. 3, August 2021: 358-371

Tabel 1. Materi pelatihan digital marketing

\begin{tabular}{|c|c|c|}
\hline Materi & & Content \\
\hline $\begin{array}{l}\text { Copy Writing } \\
\text { Pembuatan Caption pada Media Sosial }\end{array}$ & $\begin{array}{l}\text { 1) } \\
\text { 2) } \\
\text { 3) } \\
\text { 4) } \\
\text { 5) } \\
6)\end{array}$ & $\begin{array}{l}\text { Usaha melalui jalur online } \\
\text { Pentingnya copy writing } \\
\text { Kalimat promosi } \\
\text { Teknik membuat tulisan } \\
\text { Kekuatan caption } \\
\text { Penggunaan media sosial }\end{array}$ \\
\hline Digital Marketing & $\begin{array}{l}\text { 1) } \\
\text { 2) } \\
\text { 3) } \\
\text { 4) } \\
\text { 5) } \\
\text { 6) } \\
\text { 7) } \\
\text { 8) }\end{array}$ & $\begin{array}{l}\text { Strategi dalam pemasaran } \\
\text { Pemasaran internet } \\
\text { Cara pemasaran di internet } \\
\text { PPC (Pay Per Click) \& CPC (Cost Per Click) } \\
\text { SEO (Search Engine Optimization) } \\
\text { SEM (Search Engine Marketing) } \\
\text { SMO (Social Media Optimization) } \\
\text { SMM (Social Media Marketing) }\end{array}$ \\
\hline Konten Marketing Digital & $\begin{array}{l}\text { 1) } \\
\text { 2) } \\
\text { 3) } \\
\text { 4) } \\
\text { 5) } \\
\text { 6) } \\
\text { 7) }\end{array}$ & $\begin{array}{l}\text { Personal business } \\
\text { Business verification } \\
\text { Business analytic } \\
\text { Instagram } \\
\text { Feed aesthetic } \\
\text { Reach market } \\
\text { Stopping power }\end{array}$ \\
\hline Foto Produk & $\begin{array}{l}\text { 1) } \\
\text { 2) } \\
\text { 3) } \\
\text { 4) } \\
\text { 5) } \\
6)\end{array}$ & $\begin{array}{l}\text { Teknik pengambilan foto } \\
\text { Pengaturan set \& property } \\
\text { Lighting } \\
\text { Camera setting } \\
\text { Composition } \\
\text { Act }\end{array}$ \\
\hline
\end{tabular}

\section{Copy writing (pembuatan caption pada media sosial)}

Caption tidak hanya ditujukan kepada pembuatan sebuah kalimat yang menyertai gambar atau foto yang akan diunggah di media sosial. Memunculkan kalimat kreatif dengan konsep singkat, padat, jelas, dan menarik menjadi kekuatan dari materi ini. Teknik membuat seseorang bisa canggih dalam berkatakata, tentu saja dengan latihan serta melihat caption dari IKM yang lain. Inspirasi akan bisa muncul ketika cakrawala berpikir dapat menjangkau hal-hal di luar kebiasaan sehari-hari, artinya kemampuan yang tidak terbatas antara "iya" dan "tidak", atau "postif" dan negatif". Copy writing adalah teknik membuat materi pemasaran guna mempersuasi pembaca untuk melakukan sebuah tindakan sesuai dengan yang diinginkan penulis. Di sana juga ada cara memunculkan minat untuk mengenal produk, kemudian melakukan pembelian, sehingga terjadinya pembelian berikutnya. Metode yang diterapkan untuk memunculkan kemenarikan dari produk yang dilakukan posting dengan mempelajari produk terlebih dahulu atau mengenal produk secara detail, sehingga akan ada kesesuaian antara produk, foto, atau video termasuk kalimat yang menyertainya. Keunikan produk ini akan membedakan dengan produk sejenis yang sudah dimiliki oleh orang lain. Kemenarikan pembuatan content ini, adalah salah satu upaya atau strategi dalam pemilihan kata-kata yang akan digunakan dalam unggahan content. 


\section{Digital marketing}

Pengenalan terhadap internet, pemasaran serta aspek lainnya menjadi langkah awal dari penyajian materi kepada peserta pelatihan. Pemasaran internet atau pemasaran elektronik merupakan strategi yang dilakukan untuk menjalankan pemasaran suatu produk atau jasa dengan menggunakan media elektronik atau online. Optimalisasi terhadap mesin pencari atau penerima, strategi desain situs web, strategi promosi daring yang akan menghubungkan pihak yang satu dengan yang lain, cara mensiasasti email pemasaran, penggunaan media sosial sampai video atau podcasting dapat dilakukan oleh pegiat IKM. Pemahaman terhadap istilah dasar dalam digital marketing tidak hanya terbatas pada strategi pemasaran saja, namun juga alasan-alasan penggunaan internet sebagai medium promosi. Untuk itu, perlu dikenalkan tentang SEO hingga SMM. Hal ini akan bermanfaat untuk membangun brand dari produk, karena memulai membangun brand itu juga tidak mudah. Ada proses identity, design, marketing, logo, strategi, sampai membangun trust. Internet telah menjadi "wabah" global manusia modern untuk saling bertukar informasi, menjadi sumber informasi dan juga sebagai sarana untuk melakukan persuasi kepada calon konsumen (Hermawan, 2019).

\section{Konten marketing digital}

Menuju kepada konten digital marketing, maka pengetahuan serta penyadaran terhadap personal business harus dimulai sejak dini. Dengan konsep e-business yang sekarang sedang trend akan merujuk pada proses bisnis yang dikendalikan secara elektronik dan memerlukan subjek tertentu khususnya pada produk yang dihasilkan sebuah industri. Kewajiban bagi pelaku IKM dalam mempersiapkan konten digital marketing adalah personal learning, untuk bisa memprediksi pertumbuhan usaha serta memunculkan kemampuan dalam pengendalian sikap individu kepada profesionalitas. Keinginan untuk membuat konten digital mengajarkan kepada seseorang harus mampu berkreasi, memiliki inisiatif serta upaya yang dilakukan untuk meningkatkan pengetahuan serta keahlian. Melalui jejaring sosial sebagai layanan berbasis web akan membuka peluang bagi individu untuk menemukan profil produk serta mampu membangun koneksi dalam sebuah sistem.

\section{Foto produk}

Materi foto produk menekankan pada teknis praktis dalam pengambilan foto produk. Diawali dengan praktik langsung dari narasumber, sehingga peserta dapat memperhatikan terlebih dahulu teknik yang digunakan untuk foto produk. Sebelum sesi foto produk dilaksanakan, peserta harus melakukan setting mini ruang dengan kotak kecil, dan mempersiapkan property untuk mempercantik tampilan foto produk. Setelah semua property tersedia, maka diperlukan penyinaran dengan komposisi yang tepat. Materi teknik lighting juga diberikan kepada peserta, sehingga ada pemahaman secara komprehensif. Dengan smartphone yang dimiliki peserta, maka masing-masing peserta dipandu untuk melakukan setting handphone dengan ukuran tertentu. Selain beberapa materi teknis tentang teknik foto, juga penting dalam pelatihan ini adalah komposisi. Dari berbagai aspek yang ada, takaran komposisi memang tidak mudah, karena memerlukan keterpaduan dari segala aspek, baik warna, ukuran sampai penyinaran. 
ABDIMAS: Jurnal Pengabdian Masyarakat Universitas Merdeka Malang Volume 6, No. 3, August 2021: 358-371
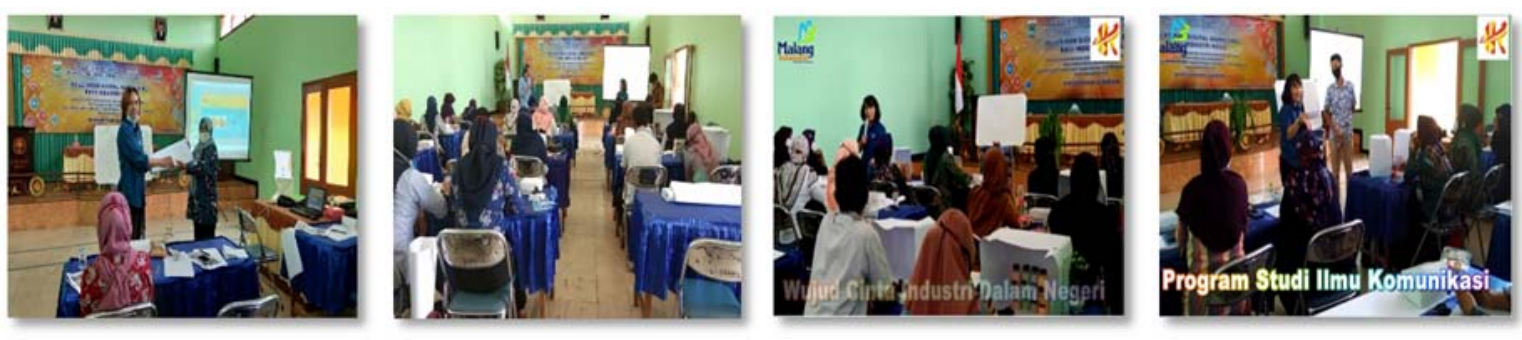

Gambar 1. Sesi presentasi narasumber

Materi pelatihan tentang pembuatan caption pada media sosial menjadi materi pertama yang disampaikan kepada peserta pelatihan. Selama ini medium yang banyak digunakan oleh peserta pelatihan adalah Whatsapp, dan untuk mengenalkan produk hanya melalui update status yang tidak setiap hari dilakukan oleh peserta pelatihan. Kendala yang dihadapi selama ini adalah kesulitan dalam membuat kata-kata yang dipadupadankan dengan gambar produk atau video. Platform kedua yang digunakan adalah Facebook dan Instagram, namun tidak begitu mendominasi, karena pegiat IKM masih mengalami kesulitan. Pengenalan berbagai platform yang dapat digunakan oleh pelaku IKM untuk bisa mengembangkan usaha dilakukan secara bertahap, sehingga dapat dipahami oleh peserta pelatihan. Pemanfaatan teknologi salah satunya adalah untuk inovasi produk dengan penggalian informasi dan data yang ada di sekitar, sehingga tampilan, rasa, cara penyajian sekaligus dapat memetakan calon konsumen dari produknya (Irianti et al., 2021; Setiyorini et al., 2018).

Konsep digital marketing setidaknya mengurangi atau dapat mengantisipasi beberapa hal yang selama ini tidak dipikirkan oleh pelaku IKM. Salah satu kekuatan dari digital marketing adalah pemanfaatan promosi dari media sosial yang memuat sebuah akun dan bisa mencantumkan link url website (Setiyaningsih \& Fahmi, 2020; Mustika, 2019). Perkembangan teknologi itu sendiri juga menjadikan internet sebagai bagian dari kehidupan masyarakat modern (Rizky \& Setiawati, 2020; Kusuma \& Sugandi, 2018). Kondisi yang ada saat ini, seakan segala aktivitas di masyarakat tidak dapat dilepaskan dari dunia maya, sehingga percepatan ini harus mampu ditangkap oleh masyarakat dengan meningkatkan ketrampilan dalam memanfaatkan internet, salah satunya untuk pemasaran digital.

Digital marketing dapat menjangkau pasar yang lebih luas secara geografis dengan konsep meminimalisir tatap muka secara langsung tetapi melalui virtual. Pemasaran online lebih menekankan pada pengenalan platform yang telah banyak digunakan oleh pelaku IKM. Kemudian juga dikenalkan tentang SEO (Search Engine Optimalization). Mengenalkan digital marketing kepada peserta pelatihan akan memberikan gambaran kepada pegiat IKM tentang peluang di dunia maya yang harus dimulai sejak dini, sehingga tidak akan tertinggal oleh pegiat IKM di wilayah lain. Sarana yang diperlukan untuk membuat content terbagi menjadi beberapa kategori yang saling berhubungan.

Pemasaran digital memang tergantung pada transmisi digital dengan keuntungan lebih mudah, lebih cepat dan lebih murah. Pada dasarnya pemasaran digital tidak hanya berkutat tentang pemahaman tentang teknologi saja, namun juga ada proses untuk memahami orang, kebiasaan orang-orang tersebut menggunakan teknologi, dan kemampuan teknologi mampu membantu kualitas dari aktivitas yang ada. Hasil dari aktivitas di dunia maya diprediksi akan menjadi hal yang paling krusial pada setiap 
aktivitas manusia khususnya dalam menjalankan bisnis, baik itu mengawali, menjalankan sampai dengan memberikan strategi untuk kelanjutan bisnis. Ketiga hal tersebut menjadi salah satu indikator dari keberhasilan bisnis, karena strategi dengan menggunakan internet ini dapat dikatakan menghidupkan usaha 24 jam, dan calon konsumen juga dapat mengakses dalam waktu yang sama.

Era saat ini disebut era digital marketing yang sudah mendarah daging pada setiap aktivitas masyarakat dengan penguasaan teknologi yang ditunjang dengan eksistensi diri dalam memanfaatkan jejaring yang ada. Langkah mudah yang bisa dilakukan oleh pegiat IKM adalah pemanfaatan media sosial yang dapat memuat konten sesuai gaya dari masing-masing IKM, karena media sosial juga dikatakan sebagai medium aktualisasi diri atau medium yang digunakan untuk pembentukan identitas produk IKM. Ketika peserta dikenalkan dengan pemanfaatan media sosial dari hal yang paling sederhana, maka konsep dasar pada akhirnya dapat dipahami oleh peserta pelatihan.
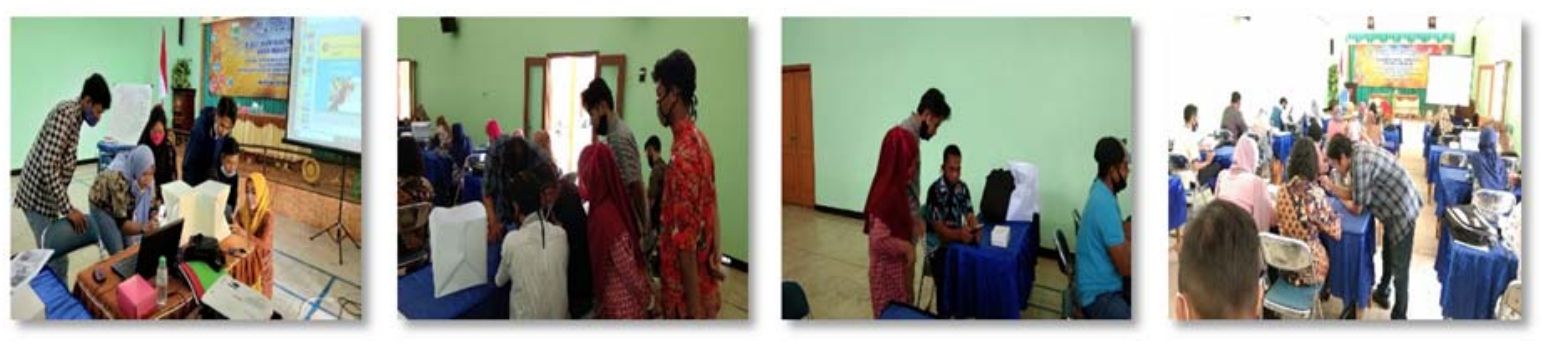

Gambar 2. Sesi praktik foto produk

\section{Pembahasan}

Kegiatan pelatihan digital marketing memiliki manfaat yang signifikan bagi peserta pelatihan, karena selama ini dalam memanfaatkan media sosial sebatas mengenalkan produk saja tanpa ada kemasan yang menarik. Hasil dunia digital yang telah diprediksi akan menjadi salah satu hal penting atau paling krusial bagi seluruh aktivitas masyarakat termasuk dalam aktivitas menjalankan usaha atau bisnis sampai memberikan tolak ukur kelanjutan dari usaha rumah tangga. Strategi bisnis dalam pemasaran dan promosi produk IKM dengan memanfaatkan media sosial, merupakan salah satu langkah yang dapat dilakukan dalam upaya memperluas jaringan pasar baik tingkat lokal maupun nasional. Dengan memahami strategi bisnis dalam pemasaran dengan menggunakan internet, akan membawa peluang untuk lebih intens dalam menjalankan promosi. Strategi ini tidak dapat diabaikan begitu saja oleh pelaku industri, karena medium ini sudah menjadi motor penggerak utama yang dijalankan secara nasional. Strategi menurut Tjiptono (2017) memuat plan, ploy, pattern, position, dan perspective. Sumber daya manusia menjadi point of interest bagi terlaksananya program yang akan berguna pada aktivitas selanjutnya (Saudah, 2020)

Saat ini pemasaran melalui internet menuntut adanya penguasaan aspek kreatif dan aspek teknis secara bersama-sama. Pemasaran melalui internet yang berorientasi pada pasar sasaran (konsumen) harus cermat dalam menyikapi keinginan dari konsumen, karena konsumen memiliki hak untuk mengambil sebuah keputusan atau menentukan pilihan. Kunci utama untuk bisa meraih calon kosumen, harus memiliki strategi untuk menciptakan strategi inovasi dan tetap menjaga kualitas dalam segala 
ABDIMAS: Jurnal Pengabdian Masyarakat Universitas Merdeka Malang Volume 6, No. 3, August 2021: 358-371

hal. Dengan pelatihan ini, maka peserta pelatihan akan semakin percaya diri dalam memasuki "pasar" melalui internet. Optimalisasi dalam hal pengetahuan tentang konsep dasar pemanfaatan internet selaras dengan upaya untuk mengupas berbagai pengalaman "jualan" melalui smartphone.

Pada kegiatan pelatihan ini, ada proses transfer of knowledge dari narasumber kepada peserta pelatihan dan juga antar peserta pelatihan terkait pengembangan dan pemasaran produk dengan memanfaatkan internet. Semakin berkembangnya internet, interaksi antarmanusia semakin mudah dengan munculnya media sosial yang dapat membagi informasi untuk bisa dimanfaatkan oleh orang lain. Media sosial adalah platform yang memfokuskan pada eksistensi pengguna yang memfasilitasi pengguna untuk dapat beraktivitas dan berkolaborasi secara online dan akan memunculkan ikatan sosial. Penggunaan media sosial bagi pegiat usaha untuk melebarkan sayap. Media sosial merupakan medium berbasis online yang pada dasarnya digunakan untuk berinteraksi antara individu atau kelompok dengan menggunakan teknologi yang terhubung ke internet atau jaringan mobile networking dengan kecepatan akses tinggi.

Penggunaan media sosial sebagai fasilitas berkomunikasi akan membawa perubahan dengan penyediaan informasi berupa teks, gambar, video dan sebagainya. Untuk memperkuat brand para pelaku IKM, tentunya materi copy writing menjadi salah satu kunci untuk bisa membuat orang familiar dengan karakter atau brand yang dibawa oleh masing-masing pegiat IKM. Copy writing adalah salah satu teknik yang dapat menghasilkan tulisan yang menarik dan membuat pembaca akan memberikan respon yang membangun. Copy writing dapat menyentuh pada semua sektor usaha yang ada di masyarakat. Teknik ini akan membuat produk semakin dikenal oleh masyarakat luas, karena mampu memunculkan tag line tertentu sesuai dengan karakter atau brand sebuah produk. Kalimat singkat dan menarik akan memberikan gambaran nyata, bahwa teknik penulisan ini dapat dilakukan dimana saja dan kapan saja.
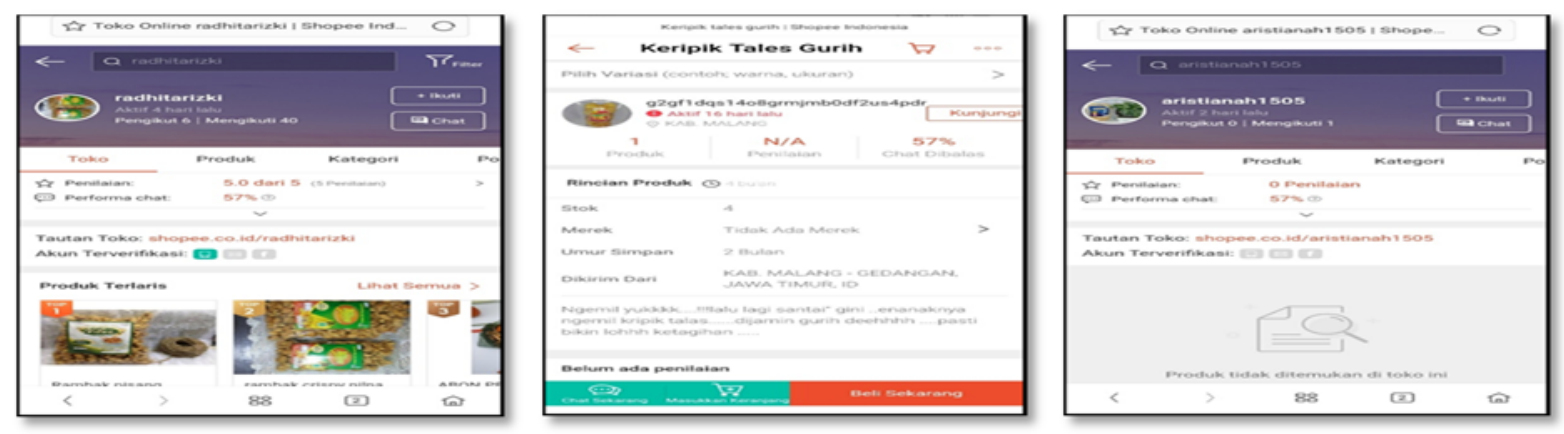

Gambar 3. Karya yang ditamplikan peserta melalui media digital marketing

Selain peserta pelatihan terampil dalam membuat caption pada media sosial, peserta pelatihan juga dapat memahami kebutuhan calon konsumen. Langkah ini menjadi penting, karena pemikiran dari pegiat IKM tidak hanya berpikir tentang keuntungan yang akan didapat saja, namun harus mampu menempatkan diri pada posisi calon konsumen yang nantinya diharapkan menjadi pelanggan yang loyal. Aktivitas engagement terhadap calon konsumen adalah berpikir untuk jangka panjang, jadi produk hasil IKM bisa bertahan lama di benak konsumen. Untuk dapat memahami keinginan dari calon konsumen, 
maka pegiat IKM dapat melakukan survai sederhana dan nantinya akan bermanfaat untuk membuat caption pada masa yang akan datang.

Diperlukan upaya yang harus terus menerus dilakukan oleh pegiat IKM untuk mencapai keberhasilan dalam memanfaatkan digital marketing. Pemasaran yang sudah ditegaskan harus memiliki strategi bisnis dalam pemasaran digital, akan berhadapan dengan kegagalan. Inisiatif dalam pemasaran digital harus dapat dimulai dari penentuan media sosial yang akan digunakan, kemudian merancang pesan yang akan disampaikan, serta menentukan teknik pemasaran yang tepat pada sasaran.

Pelatihan digital marketing ini telah membawa efek positif bagi pelaku IKM di Kecamatan Gedangan, dan masing-masing peserta pelatihan dapat memahami pentingnya penggunaan media internet untuk meningkatkan daya saing IKM. Pada awal pelatihan sudah dapat terdeteksi penggunaan smartphone di kalangan IKM, dan memang digunakan untuk menjalankan usaha, meskipun masih terbatas pada kegiatan yang sederhana. Meskipun sudah memiliki smartphone, tetap pemasaran secara konvensional tidak ditinggalkan begitu saja. Kolaborasi antara konvensional dan digital akan mampu mendobrak peningkatan penjualan dari produk IKM. Peserta pelatihan diarahkan untuk tidak menghilangkan strategi konvensional, karena lingkup wilayah serta relasi yang terjalin lebih memungkinkan untuk strategi konvensional tetap dijalankan. Kemudian diberikan sebuah pandangan, bahwa peserta pelatihan harus memiliki waktu khusus dalam mengelola jalur online.

Peserta pelatihan juga mengemukakan bahwa usaha yang telah digeluti sudah dikenal oleh masyarakat, karena masyarakat sekitar adalah lingkungan paling dekat yang bisa dijadikan kelompok sasaran primer. Keinginan dari peserta pelatihan adalah tergabung dalam komunitas IKM yang memiliki anggota dari berbagai wilayah, sehingga ada proses belajar bersama. Tidak hanya dalam lingkup yang sempit atau dalam satu wilayah saja. Pemerolehan informasi selama ini dilakukan oleh pegiat IKM melalui relasi yang terjalin secara berkelanjutan. Secara bertahap dikenalkan dengan strategi menjalin relasi, yaitu dengan memanfaatkan medium komunikasi yang sekarang banyak dimanfaatkan untuk mempermudah segala aktivitas yang dilakukan oleh masyarakat. Tentu saja hal ini menjadi salah satu faktor pengerak yang dapat memotivasi IKM untuk bersaing di lingkup lokal, nasional bahkan internasional. Dalam upaya untuk memberikan suntikan semangat, maka pendampingan dalam jangka waktu tertentu tetap dilaksanakan, dan narasumber akan tetap menjadi mentor yang melakukan controlling serta evaluasi terhadap langkah kerja dari peserta pelatihan, khususnya dalam memanfaatkan jalur online untuk mengenalkan usaha.

\section{SIMPULAN DAN SARAN}

Peserta pelatihan digital marketing telah mendapatkan informasi tentang pembuatan caption pada media sosial yang digunakan sebagai lapak jualan pelaku IKM, khususnya tentang pembuatan headline, body content, hingga closing statement. Materi yang terkait dengan digital marketing. Peserta pelatihan juga mendapatkan ketrampilan berupa teknik pengambilan foto dengan menekankan pada tingkat kejernihan gambar, visualisasi yang bermakna, sudut pandang pengambilan gambar, hingga teknik cutting. Berdasarkan hasil pelatihan yang dilakukan selama tiga hari menunjukkan adanya tanggapan yang positif dari peserta pelatihan yang ditindaklanjuti dengan pendampingan dalam kurun 
ABDIMAS: Jurnal Pengabdian Masyarakat Universitas Merdeka Malang Volume 6, No. 3, August 2021: 358-371

waktu tertentu, dan membuka ruang diskusi untuk dapat memberikan solusi dari permasalahan yang muncul. Kesulitan yang selama ini dialami oleh peserta pelatihan dapat terpecahkan dengan forum diskusi yang secara langsung, mulai dari upaya untuk memupuk rasa percaya diri dalam melakukan posting produk, strategi untuk dapat mempertahankan konsistensi dalam mengenalkan produk kepada masyarakat, sampai kepada cara komunikasi efektif yang harus dilakukan untuk merespon konsumen.

Melalui pelatihan digital marketing yang telah dilaksanakan, tentunya harus dikolaborasikan dengan pendampingan secara intens dengan sistem daring yang memungkinkan optimalisasi penggunaan media sosial sebagai media promosi. Langkah taktis lain yang bisa dijalankan adalah menindaklanjuti dengan pelatihan sejenis dalam tingkatan intermediate dengan kelompok sasaran yang telah dilakukan pendampingan, serta beberapa kelompok IKM yang telah sukses dalam memanfaatkan perkembangan teknologi komunikasi dalam setiap detail kegiatan yang terkait dengan aktivitas pemasaran. Kerjasama dapat dilakukan dalam lingkup internal, yaitu dengan sesama pelaku IKM pada wilayah yang sama atau dapat juga dilakukan dengan melakukan ekspansi untuk mencari sumber informasi lain yang mendukung keberadaan IKM di wilayah yang berbeda. Sebagaimana disyaratkan dalam konsep digital marketing, bahwa ketersediaan ruang pada dunia maya harus mampu dimanfaatkan secara efektif dan efisien oleh berbagai pihak. Untuk itu diharapkan pelaku IKM mampu menangkap peluang sebagai modal dalam mengembangan usaha yang dalam pengelolaannya terbatas namun dapat berkembang di seluruh area.

\section{DAFTAR PUSTAKA}

Djamaludin, D., Anwar, A., \& Rukmana, O. (2016). Peningkatan kemampuan usaha kecil dan menengah di Wilayah Bandung Raya dalam pemanfaatan internet sebagai sarana pemasaran dan perluasan jangkauan pasar. Ethos: Jurnal Penelitian dan Pengabdian, 4(1), 125-130. https://doi.org/10.29313/ethos.v0i0.1682

Harini, C., Darsin, \& Praptono, S. (2017). Pengembangan pemasaran kewirausahaan dalam upaya meningkatkan kinerja perekonomian unit usaha kecil menegah di Kota Semarang. Prosiding Snatif Ke-4, 537-549.

Hermawan, A. (2019). Komunikasi Pemasaran. Jakarta: Erlangga.

Irianti, N. P., Susanti, R. D. A., Triswidrananta, O. D., \& Wijaya, E. M. S. (2021). Peningkatan omset penjualan kelompok pengrajin keset melalui online marketing. Abdimas: Jurnal Pengabdian Masyarakat Universitas Merdeka Malang, 6(1), 52-60.

https://doi.org/10.26905/abdimas.v6i1.4819

Kusuma, D. F., \& Sugandi, M. S. (2018). Strategi pemanfaatan Instagram sebagai media komunikasi pemasaran digital yang dilakukan oleh Dino Donuts. Jurnal Manajemen Komunikasi, 3(1), 1833. https://doi.org/10.24198/jmk.v3i1.12963

Malangkab. (2021). Desa Gedangan. Malangkab. Retrieved from: http://gedangan.malangkab.go.id/ (Diakses pada 18 Januari 2021).

Mustika, M. (2019). Penerapan teknologi digital marketing untuk meningkatkan strategi pemasaran snack tiwul. Journal Scientific and Applied Informatics, 2(2), 165-171.

https://doi.org/10.36085/jsai.v2i2.352 
Purnamasari, V., Qurrata, V. A., \& Sudjatmiko. (2019). Peran universitas dalam pengembangan industri kecil untuk meningkatkan daya saing ekonomi lokal di Polehan Malang. Abdimas: Jurnal Pengabdian Masyarakat Universitas Merdeka Malang, 4(2), 18-22.

https://doi.org/10.26905/abdimas.v4i2.3560

Ridwan, I. M., Fauzi, A., Aisyah, I., Susilawati, S., \& Sofyan, I. (2019). Penerapan digital marketing sebagai peningkatan pemasaran pada UKM Warung Angkringan "WAGE" Bandung. Jurnal Abdimas BSI, 2(1), 137-142. https://doi.org/10.31294/jabdimas.v2i1.4974

Rizky, N., \& Setiawati, S. D. (2020). Penggunaan media sosial Instagram Haloa Cafe sebagai komunikasi pemasaran online. Jurnal Ilmu Komunikasi, 10(2), 177-190.

https://doi.org/10.15642/jik.2020.10.2.177-190

Saudah, S., \& Adi, D. S. (2018). Keseimbangan komunikasi dalam penguatan identitas komunitas kreatif telematika Kota Malang. Mediakom: Jurnal Ilmu Komunikasi, 1(2), 143-154. https://doi.org/10.32528/mdk.v1i2.1574

Saudah, S. (2020). Peer-personality engagement dalam upaya memperkuat sinerjitas dalam proses komunikasi manajemen. Jurnal Nomosleca, 6(1), 53-67.

https://doi.org/10.26905/nomosleca.v6i1.4038

Setiyaningsih, L. A., \& Fahmi, M. H. (2020). Penguatan community development petani nanas Desa Palaan melalui digital marketing. Abdimas: Jurnal Pengabdian Masyarakat Universitas Merdeka Malang, 5(2), 145- 151. https://doi.org/10.26905/abdimas.v5i2.4361

Setiyorini, E. S., Noorachmat, B. P., \& Syamsun, M. (2018). Strategi pemasaran produk olahan hasil perikanan pada UMKM Cindy Group. Manajemen IKM: Jurnal Manajemen Pengembangan Industri Kecil Menengah, 13(1), 19-28. https://doi.org/10.29244/mikm.13.1.19-28

Tjiptono, F. (2017). Strategi Pemasaran: Promosi Iklan Media Sosial Kompetitif Market (Edisi 4). Yogyakarta: Andi. 